$5-2021$

\title{
The Relationships Among Managerial Discretion, Firm Performance, And Chief Executive Officer Compensation: A Simultaneous Equations System Approach
}

Juehui Shi

Angelo State University, San Angelo

Winston T. Lin

University at Buffalo

Ngoc Cindy Pham

Brooklyn College, The City University of New York

Follow this and additional works at: https://digitalcommons.newhaven.edu/americanbusinessreview

\section{Recommended Citation}

Shi, Juehui; Lin, Winston T.; and Pham, Ngoc Cindy (2021) "The Relationships Among Managerial Discretion, Firm Performance, And Chief Executive Officer Compensation: A Simultaneous Equations System Approach," American Business Review: Vol. 24 : No. 1 , Article 7. DOI: 10.37625/abr.24.1.114-140 Available at: https://digitalcommons.newhaven.edu/americanbusinessreview/vol24/iss1/7 
The Relationships Among Managerial

Discretion, Firm Performance, and Chief

Executive Officer Compensation: A

Simultaneous Equations System Approach
American Business Review

May 2021, Vol.24(1) 114 - 140

(c) The Authors 2021, CC BY-NC

ISSN: 2689-8810 (Online)

ISSN: 0743-2348 (Print)

\author{
Juehui Shia, Winston T. Lin ${ }^{\mathrm{b}}$, and Ngoc Cindy Pham \\ https://doi.org/10.37625/abr.24.1.114-140
}

\begin{abstract}
Prior executive compensation studies overlooked the endogeneity of firm performance and the simultaneity of managerial discretion, firm performance, and CEO pay. To overcome these two shortcomings, we propose a novel simultaneous equations system model to investigate the cause-and-effect relationships among research \& development (R\&D), advertising, firm performance, and CEO compensation, which are jointly affected by CEO's tenure, age, ownership, firm size, risk, and industry. Although the feedback loops are positive between firm performance and CEO pay and between advertising and firm performance, the feedback loop is negative between $R \& D$ and firm performance. Firm size has a direct and indirect effect on $R \& D$, advertising, firm performance, and CEO pay. Large firm size may entice CEOs to invest excessively in R\&D, leading to poor performance and low pay. Our study implies that the positive relationship between firm performance and CEO pay depends upon the appropriateness of the strategic choices that CEOs make.
\end{abstract}

\title{
KEYWORDS
}

Advertising, Research \& Development (R\&D), Firm Performance and CEO Pay, Simultaneous Equation, 2-Stage and 3-Stage Least Squares Estimation Methods

\section{INTRODUCTION AND RELATED LITERATURE}

The relationship between firm performance and CEO compensation has been puzzling researchers for decades and there is still an ongoing debate on whether good firm performance leads to high CEO pay and what actually drives up CEO pay. As suggested in Lin and Shi (2020), there are two prominent competing theories that try to explain this relationship. The students of the optimal contracting school argue that CEO compensation is determined by both capital and labor markets, whereas the students of the managerial entrenchment school contend that CEO manipulates pay to serve one's own selfinterests at the cost of shareholder value. Despite numerous studies were conducted on the relationship between firm performance and CEO compensation, findings were mixed (Frydman \& Jenter, 2010). Kaplan (2008) found that CEOs were paid for good performance, while Tosi, Werner, Katz, and Gomez-Mejia (2000) discovered that the performance-pay relationship was rather weak in a meta-analysis.

We identified two main reasons for such mixed findings and the shortcomings of prior studies. First, a simple sequential regression model might suffer from the endogeneity problem. Hambrick and Mason (1984) posited that CEO's characteristics such as age, tenure, and experience could affect performance levels and strategic choices. Quigley and Hambrick (2015) found that the CEO effect on

a Angelo State University, San Angelo, Texas

b University at Buffalo, The State University of New York

c Brooklyn College, The City University of New York

Corresponding Author:

Shi (jshi@angelo.edu) 
firm performance had become increasingly significant over the 60 years. Both these two studies reveal that a performance-pay model must consider the endogenous nature of firm performance for it to be robust.

Second, the simultaneity of managerial discretion (e.g., research and development or R\&D, advertising) (Finkelstein \& Boyd, 1998; Scherer \& Ross, 1990), firm performance, and CEO compensation has been overlooked, which are jointly influenced by such contextual criteria as CEO's characteristics (e.g., age, tenure), behavior (e.g., ownership), firm size, and market condition (e.g., volatility) (Gomez-Mejia \& Wiseman, 1997; Hambrick \& Mason, 1984). Prior studies examined these endogenous variables R\&D, advertising, firm performance, and CEO pay individually but not simultaneously.

For example, Finkelstein and Boyd (1998) claimed that managerial discretion had a significant positive effect on CEO compensation. Shepherd (1972) discovered that high advertising intensity increased ROE. Using a fixed-effect OLS model, Lee (2009) found that there was no significance between advertising and firm's return but positive significance between R\&D and return and that firm size had a significant positive effect on firm performance. Beneda and Zhang (2011) observed that R\&D reduced ROA for IPO firms in the long-run. Barker and Mueller (2002) noticed that younger CEOs invested more in R\&D and that smaller firms spent more on R\&D. Hirshleifer, Low, and Teoh (2012) uncovered that longer-tenured CEOs invested more in R\&D. Kim and Lu (2011) argued that high ownership reduced firm value and that CEOs with high ownership were more risk-averse to the risky discretionary projects such as R\&D. Hogan and McPheters (1980) contended that CEO's age, tenure, and corporate sales positively led to higher CEO pay.

So far, researchers have made a great deal of efforts to seek the empirical evidence for the relationships between CEO's tenure and R\&D intensity (Miller, 1991; Barker \& Mueller, 2002), between CEO's age and R\&D intensity (Barker \& Mueller, 2002), between CEO's characteristics (e.g., age, tenure) and CEO compensation (Hogan \& McPheters, 1980; Finkelstein \& Boyd, 1998), between CEO ownership and firm value/performance (Kim \& Lu, 2011; Lilienfeld-Toal \& Ruenzi, 2014; Welbourne \& Cyr, 1996), between firm size and R\&D intensity (Barker \& Mueller, 2002), between firm size and firm performance (Lee, 2009), between market risk (e.g., beta) and firm performance (Lee, 2009), between R\&D intensity and firm performance (Lee, 2009; Beneda \& Zhang, 2011; Yeh, Chu, Sher, \& Chiu, 2010), between advertising intensity and firm performance (Shepherd, 1972; Lee, 2009), between firm performance and CEO compensation (Hogan \& McPheters, 1980; Jensen \& Murphy, 1990; Hall \& Liebman, 1998; Finkelstein \& Boyd, 1998; Tosi, et al., 2000; Kaplan, 2008), between firm size and CEO compensation (Finkelstein \& Boyd, 1998), between CEO equity and CEO compensation (Finkelstein \& Boyd, 1998), and between managerial discretion and CEO compensation (Finkelstein \& Boyd, 1998). However, the models used to investigate these relationships are sequential with the assumption of direct casual relationships and the results presented are fragmented, mixed, inconclusive, and even contradictory to each other.

Therefore, there lacks a coherent simultaneous equations system (SES) model not only to take the endogeneity of firm performance into account, but also to theoretically and empirically integrate R\&D, advertising, firm performance, and CEO pay together as shown in Figure 1. This study overcomes the two shortcomings discussed above, thus making significant contributions to executive compensation, corporate governance, strategic management, business forecasting, and applied econometrics. Having conducted a thorough literature review on CEO compensation, Frydman and Jenter (2010) concluded that the causal effects of CEO pay on manager's behavior and firm value are less than clear and still unknown. Recently, Lin and Shi (2020) proposed a seemingly unrelated regression (SUR) model to analyze the relationships among CEO pay, firm performance, and strategic coopetition. This recent publication is the first study that brings the causality-effect literature of CEO pay a step closer to simultaneity settings. 
Nevertheless, we believe that the simple direct causal relationships are insufficient to explain the complex nature of CEO compensation in a broader setting where the major effects on CEO compensation, namely, managerial discretion and firm performance, are simultaneously and jointly determined. In other words, there exists a causality dilemma, which comes first, CEO compensation or firm performance. This causality dilemma has led Smirnova and Zavertiaeva (2017) to treating CEO compensation and firm performance (proxied by ROA) as endogenous variables. Unfortunately, the authors failed to explicitly present their SES model and check the identification problem but instead report the 2 SLS estimates (referred to as the 2SLS regression estimation results pp.669-670) based on a panel sample of 330 European firms over the time period from 2009 to 2013. The 2SLS results may yield misleading conclusions and implications (see Sections 4.4 and 4.5 below). Furthermore, it is unclear as to how they handled their panel data.

The present study represents a major extension to the work by Smirnova and Zavertiaeva (2017) and the SUR study of Lin and Shi (2020) to fill the research gap revealed from our literature review. A comprehensive holistic SES model estimated by 3SLS method is needed to explain more complex cause-and-effect relationships among management-specific discretionary decisions, firm performance, and CEO compensation. The first and foremost contribution of this work is to integrate the optimal contracting theory (Kaplan, 2008), the managerial entrenchment theory (Jensen \& Meckling, 1976; Shleifer \& Vishny, 1989), and the upper echelon theory (Hambrick \& Mason, 1984) in a simultaneous equations system (SES) framework in Sections 2 and 3. We theorize that CEOs utilize their tenure, age, ownership, and other legitimizing factors such as firm size, market risk, and the nature of the industry to affect firm performance as well as to make discretionary managementspecific decisions, which ultimately and indirectly influence the board of directors and their compensations. The second contribution of this paper is to use a SES model to examine the simultaneous relationships between $R \& D$ intensity and firm performance, between advertising intensity and firm performance, and between firm performance and CEO compensation, which are jointly affected by the contextual criteria (e.g., CEO's tenure, age, ownership, firm size, volatility, industry) as outlined by Gomez-Mejia and Wiseman (1997) and Lin and Shi (2020) in Section 4. The third contribution of this study is to show that the 3SLS estimation is more accurate and efficient compared to 2SLS and OLS, and thus is the appropriate method for estimating a SES model in Sections 5 and 6.

The remainder of this paper is organized as follows. Section 2 reviews the extant CEO pay and upper management theories and explore research opportunities. Section 3 is devoted to theoretical framework and hypotheses development and Section 4 to the theories, research models and estimation methods. Section 5 presents the data used, measurement of variables, an analysis of the data, and empirical results. Section 6 discusses the results and managerial implications. Finally, Section 7 concludes and proposes a major extension for future research.

\section{THEORETICAL BACKGROUND}

Three prominent extant theories, namely, optimal contracting theory, managerial entrenchment theory, and upper echelon theory, have examined CEO compensation and the effect of CEO on organizational outcomes. Based on the optimal contracting theory, Kaplan (2008) argues that CEO pay has to be determined by firm performance and other market conditions (i.e., both economic and labor market) to properly align CEO's financial interests with firm's revenues and strategic goals. However, the optimal contracting theory tends to overemphasize the importance of firm performance, while underestimate CEO's power play or political games to influence the board of directors and subsequently CEO pay.

Opposing the optimal contracting theory, Jensen and Meckling (1976) and Shleifer and Vishny (1989) point out that CEOs are able to manipulate their compensations utilizing managerial power such 
as tenure, age, ownership and legitimizing factors such as firm size and market risk to demand for higher pay, and that CEOs make manager-specific investments not necessarily to improve firm performance but instead to make themselves hard and costly to get replaced. Although the managerial entrenchment or power theory is able to explain why the relationship between firm performance and CEO pay is weak (Tosi, et al., 2000), it overlooks the endogenous nature of firm performance, that is, firm performance can be a dependent variable according to the upper echelon theory (Hambrick \& Mason, 1984) and it overemphasizes CEO's manipulation of firm performance whereas underestimates the significance of market influences.

To undertake a more balanced approach by considering both the optimal contracting theory and managerial entrenchment theory, Gabaix and Landier (2008), Smirnova and Zavertiaeva (2017), and Lin and Shi (2020) treat the variables related to firm performance, CEO characteristics, and firm attributes as the main explanatory variables or determinants of CEO pay. However, like the optimal contracting theory and the managerial entrenchment theory, the shortcoming of this mixed approach is the underlying assumption of direct causal effect of the pay determinants on CEO compensation. This simple assumption can be challenged by the upper echelon theory (Hambrick \& Mason, 1984) that argues that the organizational outcomes and firm performance are affected by upper management's tenure, age, ownership, firm size, market risk, and other CEO and firm attributes. In other words, CEOs influence their compensations indirectly instead of directly.

Therefore, the weaknesses in the extant CEO pay theories as reviewed above motivate us to integrate the optimal contracting theory, the managerial entrenchment theory, and the upper echelon theory to better explain how CEOs are able to affect their compensations, how CEO pay is determined and what drive up the CEO pay. We feel that a non-sequential or indirect model, for instance, a simultaneous equations system (SES) model would fill the research gap assuming that the effects of pay determinants on CEO compensation are indirect and more sophisticated compared to the optimal contracting theory and the managerial entrenchment theory alone. The upper echelon serves as the bridge to integrate the optimal contracting theory and the managerial entrenchment theory. 
THEORETICAL FRAMEWORK AND HYPOTHESES

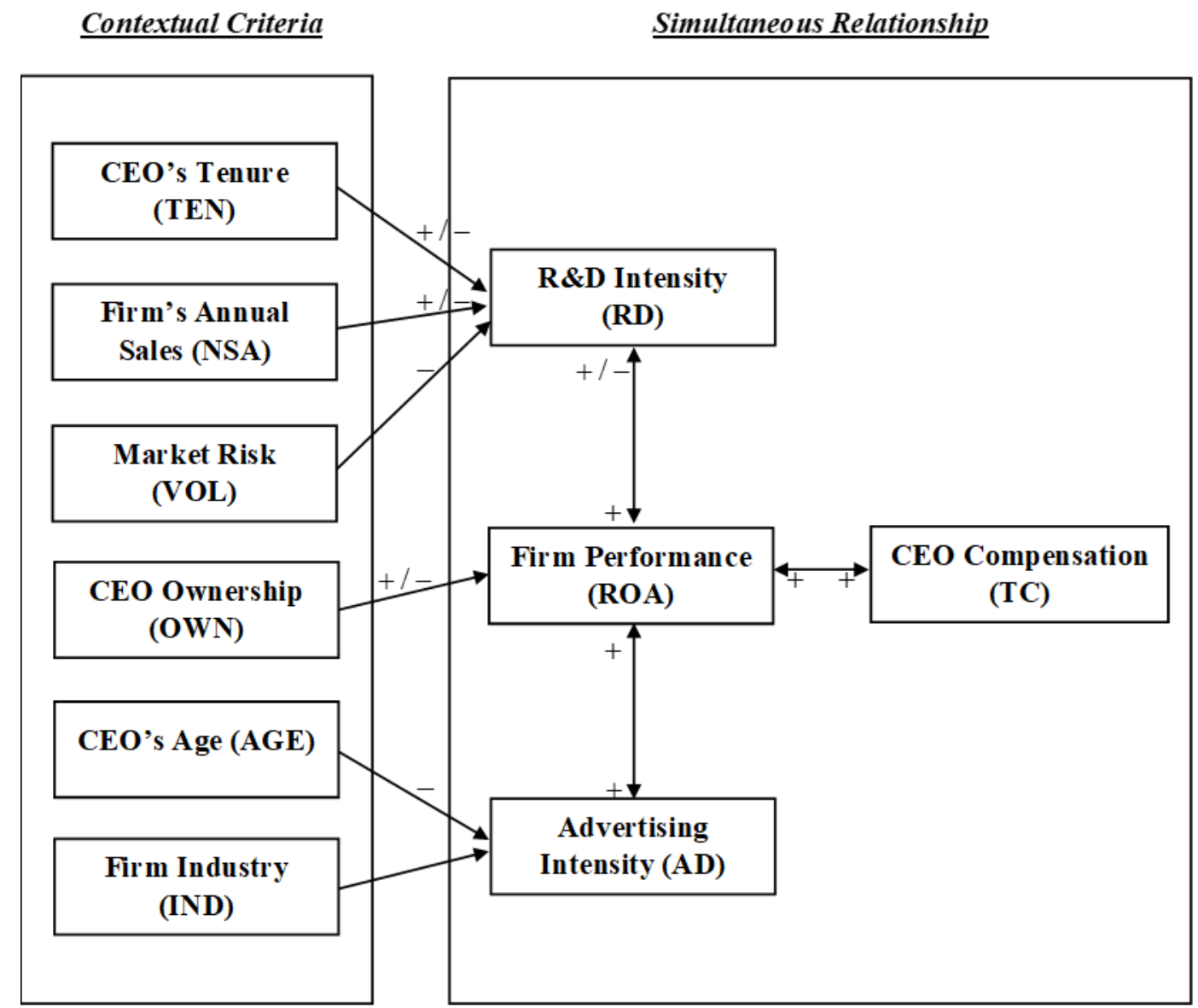

Figure 1. A Simultaneous CEO Compensation Model 
Table 1. Definitions of, and Instruments for Measuring, the Endogenous and Exogenous Variables Studied

\begin{tabular}{|c|c|c|}
\hline $\begin{array}{l}\text { Variable } \\
\text { Symbol }\end{array}$ & Definition & Instrument (Reference) \\
\hline $\mathbf{T C}_{\mathrm{i}}$ & The total CEO compensation of firm $i$ & Kaplan (2008); Tosi et al. (2000) \\
\hline $\mathbf{R O A}_{\mathbf{i}}$ & $\begin{array}{l}\text { Return on asset (a proxy used to measure } \\
\text { firm performance) }\end{array}$ & $\begin{array}{l}\text { Finkelstein \& Boyd (1998); Lin \& Chiang } \\
\text { (2011); Adam (2008) }\end{array}$ \\
\hline $\mathbf{R D}_{\mathrm{i}}$ & $\begin{array}{l}R \& D \text { intensity of firm i (measured by the } \\
\text { ratio of } R \& D \text { expenditure to sales) }\end{array}$ & Finkelstein \& Boyd (1998); Lee (2009) \\
\hline$A D_{i}$ & $\begin{array}{l}\text { Advertising intensity of firm i (measured } \\
\text { by the ratio of advertising expenditure to } \\
\text { sales) }\end{array}$ & $\begin{array}{l}\text { Shepherd (1972); Finkelstein \& Boyd (1998); } \\
\text { Lee (2009) }\end{array}$ \\
\hline TEN $_{i}$ & $\begin{array}{l}\text { CEO's tenure in years (measured by the } \\
\text { number of years hired as the CEO of firm } \\
\text { i) }\end{array}$ & $\begin{array}{l}\text { Hogan \& McPheters (1980); Miller (1991); } \\
\text { Finkelstein \& Boyd (1998); Barker \& Mueller } \\
(2002)\end{array}$ \\
\hline $\mathbf{N S A}_{i}$ & $\begin{array}{l}\text { Net sales, annual (a proxy of the firm size } \\
\text { of firm i) }\end{array}$ & Finkelstein \& Boyd (1998); Lee (2009) \\
\hline VOL $_{i}$ & $\begin{array}{l}\text { Market risk or volatility (measured by the } \\
\text { beta of firm i) }\end{array}$ & Lee (2009) \\
\hline $\mathrm{OWN}_{\mathrm{i}}$ & $\begin{array}{l}\text { CEO's ownership (the value of shares } \\
\text { owned by the CEO of firm i) }\end{array}$ & $\begin{array}{l}\text { Kim \& Lu (2011); Lilienfeld-Toal \& Ruenzi } \\
\text { (2014); Welbourne \& Cyr (1996) }\end{array}$ \\
\hline$A_{G} E_{i}$ & CEO's age of firm i (measured in years) & $\begin{array}{l}\text { Hogan \& McPheters (1980); Barker \& Mueller } \\
\text { (2002) }\end{array}$ \\
\hline$I^{\prime N D_{i}}$ & An industry control variable & A control variable \\
\hline
\end{tabular}

Figure 1 presents our theoretical framework and Table 1 lists the definitions of the variables we implement in the simultaneous CEO compensation model. We theorize that CEOs utilize their tenure, age, ownership, and other legitimizing factors such as firm size, market risk, and the nature of the industry to affect firm performance as well as to make discretionary management-specific decisions, which ultimately and indirectly to influence the board of directors and their compensations as shown in Figure 1. The major contribution of this model is the new assumption of covert influential power of CEO on firm performance and management-specific decisions along with the intertwining simultaneous relationships among management-specific decisions, firm performance, and CEO pay. Our theory improves but diverges from both the optimal contracting theory proposing that CEO pay should be determined directly by firm performance and the managerial entrenchment theory arguing that CEO's power or political play on management-specific discretionary decisions outweighs firm performance in determining CEO compensation.

Here, we state the reasons for employing the variables studied in our SES model. Gomez-Mejia and Wiseman (1997) contended that it was crucial to study CEO compensation by considering those contextual criteria, namely, CEO's characteristics, manager's behavior, firm's attributes, and market condition. The upper echelon theory proposed by Hambrick and Mason (1984) suggested that CEO's characteristics had significant impact on firm performance (or organizational outcome). Additionally, Barker and Mueller (2002) demonstrated that CEO's characteristics affected managerial discretion such as R\&D expenditure. Following the progression made by prior research, this study considers six important contextual criteria: CEO's tenure (TEN), age (AGE), ownership (OWN), firm size (NSA), industry (IND), and market risk (VOL). In this paper, we assume that ownership is exogenously 
determined (Morck, Shleifer, \& Vishny, 1988; McConnell \& Servaes, 1990), which is consistent with both the agency theory of incentive alignment (Jensen \& Meckling, 1976) and the rent extraction theory (Stulz, 1988). However, it should be noted that the assumption of ownership can also be endogenous (Demsetz \& Lehn, 1985; Himmelberg, Hubbard, \& Palia, 1999), depending on the research questions and objectives.

Finkelstein and Boyd (1998) identified seven important indicators for measuring managerial discretions: market growth (Boyd, 1990), R\&D intensity and advertising intensity (used to evaluate product differentiability) (Scherer \& Ross, 1990), demand instability (Boyd, 1990), capital intensity, concentration (industry structure) (Boyd, 1990; Schmalensee, 1977), and regulation. This paper considers two important factors: R\&D intensity and advertising intensity, which are the most prominent and relevant to studying CEO compensation and CEO's decision as discussed in Section 1. In the follow sections, we explain each relationship in the simultaneous CEO compensation model (see Figure 1) one-by-one.

\section{THE RELATIONSHIP BETWEEN CEO'S TENURE AND R\&D INTENSITY}

Hambrick and Fukotomi (1991) argue that CEO power on the board increases during the passage of time from cumulative success, good track record, and significant amount of stock options. Miller, Vries, and Toulouse (1982) argue that high tenure gives CEOs enough time to influence the organizational structure and environment. Shleifer and Vishny (1989) assert that longer tenure grants CEOs more discretions on manager-specific investments which are not necessarily value-maximizing but to make CEOs much costlier to be replaced, and hence enable CEOs to entrench themselves. Therefore, it is hypothesized that:

Hypothesis $1 \mathrm{~A}(\mathrm{H} \mathbf{1 A})$. R\&D intensity (RD) increases as CEO's tenure (TEN) increases.

On the contrary, the stability and status quo enjoyed by the CEOs who stay longer in the organization makes them less likely to embrace changes and innovation (Hambrick \& Mason, 1984). Moreover, longer tenure may prohibit CEOs from expanding the business and making risky decisions necessary to evolve the organization (Miller, 1991; Barker \& Mueller, 2002). Thus, the alternative hypothesis is given by:

Hypothesis 1B (H1B). R\&D intensity (RD) decreases as CEO's tenure (TEN) increases.

\section{THE RELATIONSHIP BETWEEN FIRM SIZE AND R\&D INTENSITY}

According to the resource-based view, larger firms invest more in R\&D than smaller firms do. Schumpeter (1942) argues that larger firms have sufficient resources and more market power to innovate and protect their investments from immediate imitation. Galbraith (1952) contends that larger firms are more capable of taking on the risk and time associated with a R\&D project. Arrow (1962) asserts that smaller firms have less incentives for innovation because of the lack of financial resources, the difficulty in protecting the property rights after commercialization, and the high risk of failure and imitation. Hence, we hypothesize that:

Hypothesis $2 A(H 2 A)$. R\&D intensity (RD) increases as firm size (NSA) increases. 
Barker and Mueller (2002) put forward a counter argument that uncertain and risky R\&D spending may disturb the status quo of a strong market place the larger size had created. Then, the alternative hypothesis states that:

Hypothesis 2B (H2B). R\&D intensity (RD) decreases as firm size (NSA) increases.

\section{THE RELATIONSHIP BETWEEN MARKET RISK AND R\&D INTENSITY}

R\&D projects typically involve huge risk and more failures (Perlitz, Peske, \& Schrank, 2002), thus low market risk or volatility would give firms more incentives to innovate. CEOs are more likely to take on risky propositions when the risks are low. Accordingly, we are interested in testing:

Hypothesis $3\left(\mathrm{H}_{3}\right)$. R\&D intensity $(\mathrm{RD})$ increases as market risk (VOL) decreases.

\section{THE RELATIONSHIP BETWEEN CEO'S OWNERSHIP AND FIRM PERFORMANCE}

Agency theorists (Tosi \& Gomez-Mejia, 1994) claim that CEO ownership serves as an incentive alignment mechanism that closely ties agent's (CEO's) interests with principle's (stakeholder's) interests, and hence to mitigate the classic agency problems. By design, CEOs will unlikely to take on highly risky projects and will make more rational business decisions in order to keep their job. In theory, when companies perform well on the market, CEOs will benefit from owning more shares and stakeholders will profit from strategic superiority. A recent study by Lilienfeld-Toal and Ruenzi (2014) shows that substantial CEO ownership (e.g., more than $10 \%$ of outstanding shares) leads to higher firm value. Consequently, it calls for testing:

Hypothesis 4A (H4A). Firm performance (ROA) increases as CEO ownership (OWN) increases.

On the contrary, Jensen and Meckling (1976) argue that CEOs are able to entrench themselves through higher ownership that gives them significant power and control over the board. Shleifer and Vishny (1989) argue that entrenched managers tend to make investments which are not valuemaximizing but simply make the managers appear to be valuable to the shareholders. Welbourne and Cyr (1996) find that high levels of CEO ownership hinder performance for firms at all levels of risk. Consequently, it also calls for testing:

Hypothesis 4 (H4B). Firm performance (ROA) decreases as CEO ownership (OWN) increases.

\section{THE RELATIONSHIP BETWEEN CEO'S AGE AND ADVERTISING INTENSITY}

The upper echelons theory of Hambrick and Mason (1984) posit that younger managers are likely to generate greater growth (Child, 1974; Hart \& Mellons, 1970) and variability in profit than their older counterparts do. Shepherd (1972) discovers that intensive advertising significantly drives up firm's return in profit. As such, we propose to test:

Hypothesis $\mathbf{5}\left(\mathrm{H}_{5}\right)$. Advertising intensity (AD) increases as CEO's age (AGE) decreases. 


\section{THE RELATIONSHIP BETWEEN FIRM PERFORMANCE AND R\&D INTENSITY}

High performance may give managers a sense of success which in turn boosts CEO's confidence to pursue risky projects. In fact, Hirshleifer, Low, and Teoh (2012) discover that overconfident CEOs spend more on R\&D and have higher return on innovation. High performance may also convince CEOs that they are in better control of their firms which in turn promotes risk-taking behavior. Based on the congruence theory (Nightingale \& Toulouse, 1977), Miller, Vries, and Toulouse (1982) argue that the internal managers, who believe their own actions affect the organizational outcomes, are more likely to innovate. The above analyses suggest to test:

Hypothesis 6A (H6A). R\&D intensity (RD) increases as firm performance (ROA) increases.

On the other hand, Cyert and March (1963) contend that low-performing firms are inclined to engage in innovation hoping that it can boost stagnated performance. Thus, the alternative hypothesis to be tested is described by:

Hypothesis 6B (H6B). R\&D intensity (RD) increases as firm performance (ROA) decreases.

\section{THE RELATIONSHIP BETWEEN FIRM PERFORMANCE AND ADVERTISING INTENSITY}

In order for firms to be at a superior market position, product differentiation is required (Lee, 2009). Shepherd (1972) argues that high advertising intensity is one of the sources for product differentiability and a market barrier factor for profitability. Therefore, it is hypothesized that:

Hypothesis $7\left(\mathrm{H}_{7}\right)$. Advertising intensity $(A D)$ increases as firm performance $(R O A)$ increases.

\section{THE EFFECTS OF R\&D INTENSITY AND ADVERTISING INTENSITY ON FIRM PERFORMANCE}

According to Amato and Wilder (1985), Mueller (1990), Amato and Amato (2004), Bain (1956), and Lee (2009), entry barriers such as advertising and $R \& D$ expenditures significantly increase the degree of market power and subsequently profitability. The theory implies that the more the company spends on $R \& D$ and advertising spending, the more likely it is going to deter the new competitors from entering the existing market, who are lack of sufficient financial resources to be at a competitive position. Hence, two hypotheses are established as follows:

Hypothesis 8 (H8). Firm performance (ROA) increases as R\&D activity intensifies (RD).

Hypothesis 9 (H9). Firm performance (ROA) increases as advertising activity intensifies (AD).

\section{THE IMPACT OF CEO'S PAY ON FIRM PERFORMANCE}

According to the two-factor theory or the Herzberg, Mausner, and Snyderman's (1959) motivationhygiene theory, low hygiene such as low pay can cause many complaints at the workplace, in general, dissatisfaction with the job. Maslow $(1943,1954)$ argues that five needs (e.g., physiological, safety, love, esteem, and self-actualization) motivate people. Since CEO compensation data are publicly available, inadequate or uncompetitive pay can make CEOs feel less confident about their job performance and hence less respected by their peers. The Hawthorne effect (Gillespie, 1991; Mayo, 1946, 1975; Roethlisberger \& Dickson, 1939) also applies here. Well paid CEOs feel being paid more 
attention by their upper management, and therefore work much harder. The expectancy theory posits that people behave accordingly to what they are expecting (Vroom, 1964; Oliver, 1974). Thus, it is probable that CEOs will work much harder if they are expecting a pay raise. Since such expectation is based on the past record of pay, low pay demotivates CEOs, and consequently lead to productivity deficiency. Drawing from those psychology theories of motivation, we expect that well paid CEOs will be more content with their job, be more productive, and thus generate higher firm performance. Therefore, we hypothesize that:

Hypothesis 10 (H10). Firm performance (ROA) increases as CEO pay (TC) increases.

\section{THE INFLUENCE OF FIRM PERFORMANCE ON CEO'S PAY}

The agency theorists argue that CEO pay has to be strongly tied to firm performance in order to reflect shareholders' best interests and deter any divergent behavior from a CEO (Tosi \& Gomez-Mejia, 1989). In fact, Kaplan (2008) finds the evidence that CEOs are indeed paid for performance, but not efficiently due to market inefficiency. Lin and Shi's (2020) seemingly unrelated regression (SUR) model indicates that the peer-pay bias is one of the reasons for pay inefficiency. Thus, a final hypothesis to be tested is given by:

Hypothesis 11 (H11). CEO pay (TC) increases as firm performance (ROA) increases.

\section{RESEARCH MODELS AND ESTIMATION METHODS}

\section{THEORIES}

There are two competing theories of CEO compensation (Lin \& Shi, 2020): (i) The theory of managerial entrenchment theorizes that CEO pay is affected by CEO's managerial power (Jensen \& Meckling, 1976; Shleifer \& Vishny, 1989) such as tenure, ownership, and age as well as legitimizing factors (Tosi, Jr. \& Gomez-Mejia, 1989, providing an agency theory perspective) such as firm size and market risk; and (ii) the theory of optimized contracting (Kaplan, 2008) theorizes that CEO pay is determined by firm performance measured by return on asset (ROA), sales, net income, etc. as well as by competitive labor market. A hybridity theory (Gabaix \& Landier, 2008; Smirnova \& Zavertiaeva, 2017; Lin \& Shi, 2020; among others) was born as a mixture of the above two theories. The research methods and models developed and constructed based upon these theories are sequential, with assumed direct causaleffect relationships (with CEO pay as the effect or dependent variable), including regression models and SUR approach (Lin \& Shi, 2020).

The problem of the so-called endogeneity may arise from the applications of the direct causal-effect models (Zellner \& Theil, 1962; Theil, 1971; Wu, 1973; Hausman, 1978; Kmenta, 1997; Greene, 2012). One of the resolution of the endogeneity problem calls for simultaneity, that is, the construction of a simultaneous equations system (SES) based on the theoretical foundations as described above to examine the simultaneously determined relationships among CEO compensations, firm performance, R\&D intensity, and advertising intensity. The literature of CEO pays has overlooked the problem of endogeneity and the need to pay attention to the simultaneity nature of CEO pays, firm performance, and other variables. To bridge this research gap, we propose a SES which is composed of two components, namely, the structural form and the reduced form. 


\section{THE STRUCTURAL FORM}

The coefficients of the structural form of the SES is used to test the hypotheses developed from the theoretical simultaneous CEO compensation model (see Figure 1) as described in the preceding section. Here, we present the structural form as follows:

$T C_{i}=\beta_{10}+\beta_{11} R O A_{i}+\varepsilon_{1 i}$

$R O A_{i}=\beta_{20}+\beta_{21} T C_{i}+\beta_{22} R D_{i}+\beta_{23} A D_{i}+\beta_{24} O W N_{i}+\varepsilon_{2 i}$

$R D_{i}=\beta_{30}+\beta_{31} R O A_{i}+\beta_{32} T E N_{i}+\beta_{33} N S A_{i}+\beta_{34} V O L_{i}+\varepsilon_{3 i}$

$A D_{i}=\beta_{40}+\beta_{41} R O A_{i}+\beta_{42} A G E_{i}+\beta_{43} I N D_{i}+\varepsilon_{4 i}$

where $i=1, \ldots, m$ and $\mathrm{m}$ is the sample size of firms.

The structural model, Eqs. (4.1) - (4.4), involves ten (10) variables. Four $\left(T C_{i}, R O A_{i}, R D_{i}, A D_{i}\right)$ of them are the endogenous (jointly dependent) variables, while the other six variables $\left(O W N_{i}, T E N_{i}\right.$, $N S A_{i}, V O L_{i}, A G E_{i}$, and $\left.I N D_{i}\right)$ are the exogenous variables. The definitions of those ten variables are included in Table 1 for easy reference. Here, we provide a summary of their brief definitions: $T C_{i}=$ the total of CEO compensation of firm $i, R O A_{i}=$ return on asset, $R D_{i}=$ R\&D intensity, $A D_{i}=$ advertising intensity, $T E N_{i}=$ the CEO's tenure, $N S A_{i}=$ annual net sales, $V O L_{i}=$ market volatility, $A G E_{i}=$ the CEO's age, $O W N_{i}=$ the CEO's ownership, and $I N D_{i}=$ industry representing a control variable.

We now turn to explaining the relationship of each explanatory variable in each equation of the structural form with the dependent (endogenous) variable. First, Eq. (4.1) is based on the theory of optimal contracting by assuming that $T C_{i}$ is linearly related to the firm's performance that with proxy by the firm's $R O A_{i}$, but that $T C_{i}$ is simultaneously and jointly determined with $R O A_{i}$. As such, there is no exogenous variable involving in Eq. (4.1).

Second, Eq. (4.2) specifies that $R O A_{i}$ is linearly impacted by the explanatory (exogenous) variable, $O W N_{i}$ and three jointly dependent (endogenous) variables i.e., $T C_{i}, R D_{i}$, and $A D_{i}$, but that $R O A_{i}$ is simultaneously determined with these three dependent variables.

Third, Eq. (4.3) depicts that the dependent variable, $R D_{i}$, is linearly effected by three explanatory (exogenous) variables, namely, $T E N_{i}, N S A_{i}$, and $V O L_{i}$, and that $R D_{i}$ is jointly determined with $R O A_{i}$.

Fourth (final), Eq. (4.4) establishes that the dependent variable, $A D_{i}$, is linearly affected by two explanatory (exogenous) variables, that is, $A G E_{i}$ and $I N D_{i}$, but that $A D_{i}$ is simultaneously and jointly determined with $R O A_{i}$.

To sum up, the structural form is designed to examine the simultaneous relationships between CEO compensations and firm performance (Eqs. 4.1 and 4.2) as viewed by the optimal contracting theory, between R\&D intensity and firm performance (Eq. 4.3), and between advertising intensity and firm performance (Eq.4.4). The SES model also incorporates several exogenous variables suggested by the managerial entrenchment theorists, such as CEO's tenure, ownership, and age, as well as market risk and firm size with proxy by annual net sales.

In the structural form (4.1) - (4.4), CEO's characteristics (tenure or TEN; age or AGE), managerial behavior (ownership or OWN), firm size (with proxy by sales or NSA), firm's attribute (industry or IND), and firm market condition (volatility or VOL) are the chosen exogenous variables of the model. CEO compensation (TC), firm performance (proxy by the return on assets or ROA), and the manager's discretionary decisions (R\&D or RD; advertising or $A D$ ) are the jointly-determined endogenous 
variables that are simultaneously determined and interdependent. Thus, there are four equations in the system because there are four jointly-determined endogenous variables.

The relationships among the hypotheses presented in the theoretical simultaneous CEO compensation model and the associated coefficients of the structural form are summarized in Table 2, where the dependent variables are highlighted in bold and the independent variables are presented in normal font.

Table 2. Relationships Among Hypotheses and Structural Coefficients

\begin{tabular}{|c|c|c|c|}
\hline Relationship & Hypothesis & Coefficient & Sign \\
\hline $\begin{array}{l}\text { CEO's tenure (TEN) } \\
\text { R\&D intensity (RD) }\end{array}$ & $H_{1} A / H_{1} B$ & $\beta_{32}$ & $+/-$ \\
\hline $\begin{array}{l}\text { Firm's annual sales (NSA) } \\
\text { R\&D intensity (RD) }\end{array}$ & $\mathrm{H}_{2} \mathrm{~A} / \mathrm{H}_{2} \mathrm{~B}$ & $\beta_{33}$ & $+/-$ \\
\hline $\begin{array}{l}\text { Market risk (VOL) } \\
\text { R\&D intensity (RD) }\end{array}$ & $\mathrm{H}_{3}$ & $\beta_{34}$ & - \\
\hline $\begin{array}{l}\text { CEO ownership (OWN) } \\
\text { Firm performance (ROA) }\end{array}$ & $\mathrm{H}_{4} \mathrm{~A} / \mathrm{H}_{4} \mathrm{~B}$ & $\beta_{24}$ & $+/-$ \\
\hline $\begin{array}{c}\text { CEO's age (AGE) } \\
\text { Advertising intensity (AD) }\end{array}$ & $\mathrm{H}_{5}$ & $\beta_{42}$ & - \\
\hline $\begin{array}{c}\text { R\&D intensity (RD) } \\
\text { Firm performance (ROA) }\end{array}$ & $\mathrm{H} 6 \mathrm{~A} / \mathrm{H} 6 \mathrm{~B}$ & $\beta_{31}$ & $+/-$ \\
\hline $\begin{array}{l}\text { Advertising intensity (AD) } \\
\text { Firm performance (ROA) }\end{array}$ & $\mathrm{H} 7$ & $\beta_{41}$ & + \\
\hline $\begin{array}{l}\text { Firm performance (ROA) } \\
\text { R\&D intensity (RD) } \\
\text { Advertising intensity (AD) }\end{array}$ & $\begin{array}{l}\mathrm{H} 8 \\
\mathrm{H} 9\end{array}$ & $\begin{array}{l}\beta_{22} \\
\beta_{23}\end{array}$ & $\begin{array}{l}+ \\
+\end{array}$ \\
\hline $\begin{array}{l}\text { Firm performance (ROA) } \\
\text { CEO compensation (TC) }\end{array}$ & $H_{10}$ & $\beta_{21}$ & + \\
\hline $\begin{array}{l}\text { CEO compensation (TC) } \\
\text { Firm performance (ROA) }\end{array}$ & H11 & $\beta_{11}$ & + \\
\hline
\end{tabular}

\section{IDENTIFICATION}

An equation is identified if its statistical form is unique, which allows the parameters to be estimated from the sample. An equation is under-identified if its statistical form is not unique. An equation is either over-identified or exactly-identified if it is not under-identified (Lin \& Shao, 2000). In order for the SES to be identified and estimated, the equations in the system must be identified (i.e., either overidentified or just-identified). The rule of identification is that the number of exogenous variable(s) in an equation extracted (or excluded) from the total number of exogenous variables in the SES must be greater than (over-identification) or equal to (exact-identification) the number of endogenous variables included in the equation minus 1 . For a system to be identified (over- or just-identified), all the equations in the system must be identified. This order condition is satisfied if an equation can be properly identified (Goldberger, 1964; Kmenta, 1997; Greene, 2012). 
Applying the identification rule to Eqs. (4.1) - (4.4) of the proposed SES, we find that Eqs. (4.1) (4.4) are over-identified. None of the equations in the system is under-identified. Therefore, there is no identification problem.

\section{THE REDUCED FORM AND THE RELATIONSHIP WITH THE STRUCTURAL FORM}

We can derive the reduced form from the structural form by a series of mathematical and matrix operations (see Goldberger, 1964; Kmenta, 1997; Lin and Shao, 2000; Greene, 2012). The reduced form is composed of Eqs. (4.5) - (4.8), the counterparts of the structural form Eqs. (4.1) - (4.4):

$$
\begin{aligned}
& T C_{i}=\pi_{10}+\pi_{11} \text { TEN }_{i}+\pi_{12} N S A_{i}+\pi_{13} V O L_{i}+\pi_{14} O W N_{i}+\pi_{15} A G E_{i}+\pi_{16} I N D_{i}+w_{1} \\
& R O A_{i}=\pi_{20}+\pi_{21} T E N_{i}+\pi_{22} N S A_{i}+\pi_{23} V O L_{i}+\pi_{24} O W N_{i}+\pi_{25} A G E_{i}+\pi_{26} I N D_{i}+w_{2} \\
& R D_{i}=\pi_{30}+\pi_{31} T E N_{i}+\pi_{32} N S A_{i}+\pi_{33} V O L_{i}+\pi_{34} O W N_{i}+\pi_{35} A G E_{i}+\pi_{36} I N D_{i}+w_{3} \\
& A D_{i}=\pi_{40}+\pi_{41} T E N_{i}+\pi_{42} N S A_{i}+\pi_{43} V O L_{i}+\pi_{44} O W N_{i}+\pi_{45} A G E_{i}+\pi_{46} I N D_{i}+w_{4}
\end{aligned}
$$

Each of the Eqs. (4.5) - (4.8) indicates that a jointly-determined endogenous variable depends on all of the pre-determined exogenous variables and a random error. Therefore, we can find the total effect (sum of the reduced-form coefficient estimates) of the exogenous contextual criteria variables on an endogenous variable (Lin and Shao, 2000).

\section{ESTIMATION PROBLEM AND METHODS: OLS VS. 2SLS VS. 3SLS}

In an equation of the SES models, an endogenous variable appears as an independent variable. Then, it can be shown that the expected value of the product of the endogenous variable and the equation's random error is not equal to zero because the endogenous variable and the random error are correlated or not independent. As an illustrative example, in Eq. (4.1), it can be proved that $E\left(R O A_{i} \varepsilon_{1 i}\right) \neq 0$, raising a serious problem called endogeneity.

Consequently, it is invalid to estimate the SES by using the ordinary least squares (OLS), because the OLS estimates of the structural coefficients are biased and inconsistent due to the problem of endogeneity caused by the simultaneity bias or simultaneous-equation bias (Koutsoyiannis, 1977; Kmenta, 1997; Lin \& Shao, 2000). Therefore, the two-stage least squares (2SLS) and the three-stage least squares ( $3 \mathrm{SLS}$ ) methods have to be applied. The former is a single-equation method applied to estimate each individual equation in the SES, while the latter is a complete system method applied to estimate the whole SES (i.e., all the equations in the SES simultaneously). It has been established theoretically and empirically that 3SLS is more efficient than 2SLS (e.g., Kmenta, 1997; Lin, 1987, 1992; Lin and Shao, 2000). As such, the use of the 2SLS estimates to draw the conclusions represents a serious draw back of the work by Smirnova and Zavertiaeva (2017).

According to Zellner and Theil (1962), 3SLS is asymptotically more accurate, optimal, and efficient than 2 SLS when the cross-equation random errors are correlated (i.e., $E\left(\varepsilon_{j} \varepsilon_{k}\right) \neq 0$, for $j, k \in\{1,2,3,4\}$ and $j \neq k$ ). The assumption of such correlations among the random errors (or the so-called contemporaneous correlations) differs 3 SLS from 2 SLS. The cross-equation random errors could be correlated if other possible exogenous variables are unintentionally omitted from the simultaneous CEO compensation model, leaving the effects of those omitted variables to be absorbed by the random errors and making the random errors correlated. 


\section{DATA AND EMPIRICAL RESULTS}

\section{DATA}

We collected our sample data from Execucomp Annual Compensation (Compustat quarterly updates), Execucomp Company Financial-Fundamentals Annual of North America (Compustat Monthly Updates), and Beta Deciles of Stock/Portfolio Assignments (The Center for Research in Security Prices or (RSP). The database is provided by the Wharton Research Data Services (WRDS). The firms that considered the strategic choices, namely, R\&D and advertising in 2013 were chosen for our sample. The sampled firms also include those that considered R\&D and advertising but decided not to spend on R\&D and/or advertising in 2013. The sample would be biased if those firms were not included. We took the following steps to narrow down the sample firms. First, the firms with no or incomplete information on CEO compensation (TC), return on assets (ROA), CEO's tenure (TEN), CEO's age (AGE), CEO ownership (OWN), sales (NSA), and market risk beta (VOL) were excluded, resulting in 1641 initial sample firms. Next, we also excluded those firms with no or incomplete information on both R\&D expenditure (XRD) and advertising expenditure (XAD), leading to 437 final sample firms that were used to estimate the simultaneous CEO compensation model (Eqs. (4.1)-(4.4)) and test the hypotheses presented in Section 2 above and Figure 1.

\section{MEASUREMENT OF VARIABLES}

Several previous studies that are useful and relevant to this paper are used as guidelines to measure the variables considered in the simultaneous CEO compensation model. They are listed in Table 1.

CEO's tenure $\left(T E N_{i}\right)$ is measured as the time duration during which an executive has served as a CEO. Net sales annual $\left(N S A_{i}\right)$ is used as a proxy for firm size. Market risk (or volatility) $\left(V O L_{i}\right)$ is measured by beta. CEO ownership $\left(O W N_{i}\right)$ is measured by the value of shares (excluding options) owned by a CEO. CEO's age $\left(A G E_{i}\right)$ is measured in years. Industry control $\left(I N D_{i}\right)$ is a control variable for which we assign an ordinal code from 1 to 9 based on the first two-digit Global Industry Classification Standard (GICS) code provided by the database. The sample data involve 9 sectors, namely, Energy (10), Materials (15), Industrials (20), Consumer Discretionary (25), Consumer Staples (30), Health Care (35), Financials (40), Information Technology (45), and Telecommunication Services (50).

Total CEO compensation $\left(T C_{i}\right)$ comprises salary, bonus, other annual pay, total value of restricted stock grants, total value of stock options granted calculated by Black-Scholes, long term incentive pay (LTIP), and all other total pay. Return on assets $\left(R O A_{i}\right)$ is used as a proxy for firm performance, measured as the ratio of net income to total assets. R\&D intensity $\left(R D_{i}\right)$ is measured as the ratio of R\&D expenditure to sales. Advertising intensity $\left(A D_{i}\right)$ is measured as the ratio of advertising expenditure to sales.

\section{DATA ANALYSIS}

The summary statistics for the endogenous variables and exogenous variables and the correlation matrix are presented in Tables 3 and 4 respectively. 
Table 3. Summary Statistics for the Exogenous and Endogenous Variables in the SES Model

\begin{tabular}{ccccccccccc}
\hline Variable & TEN & NSA & VOL & \multicolumn{1}{c}{ OWN } & AGE & IND & TC & ROA & RD & AD \\
\hline Mean & 8.476 & 96.701 & 1.071 & 5.589 & 56.236 & 5.542 & 6.450 & 5.845 & 6.176 & 2.366 \\
Std. dev. & 7.525 & 312.974 & 0.457 & 59.270 & 7.328 & 1.955 & 6.329 & 10.021 & 8.813 & 3.788 \\
\hline
\end{tabular}

Table 4. Correlation Matrix for the Exogenous and Endogenous Variables in the SES Model

\begin{tabular}{ccccccccccc}
\hline$\widehat{\boldsymbol{\rho}}_{\boldsymbol{i j}} \boldsymbol{j}^{\prime}$ & TEN & NSA & VOL & OWN & AGE & IND & TC & ROA & RD & AD \\
\hline TEN & 1 & -0.093 & -0.012 & 0.194 & 0.390 & 0.046 & -0.065 & -0.121 & 0.108 & -0.091 \\
NSA & 1 & -0.081 & 0.074 & 0.076 & -0.047 & 0.267 & 0.065 & -0.089 & -0.013 \\
VOL & & 1 & 0.039 & -0.040 & -0.080 & 0.019 & -0.080 & 0.035 & -0.006 \\
OWN & & & 1 & 0.023 & 0.090 & 0.394 & 0.037 & 0.074 & -0.025 \\
AGE & & & & 1 & -0.196 & 0.024 & -0.039 & -0.138 & -0.033 \\
IND & & & & & 1 & -0.004 & -0.120 & 0.570 & -0.030 \\
TC & & & & & & 1 & 0.135 & 0.026 & 0.101 \\
ROA & & & & & & & 1 & -0.243 & -0.001 \\
RD & & & & & & & & 1 & -0.094 \\
AD & & & & & & & & & 1 \\
\hline
\end{tabular}

$5 \%$ critical value (two-tailed) $=0.0938$ for $n=437$.

In Table 3, the average CEO's tenure (TEN) is 8.476 years. The average sales (NSA) is 96.701 hundred million dollars. The average market risk (VOL) is 1.071 beta deciles. The average CEO ownership (OWN) is 5.589 million dollars. The average CEO's age (AGE) is 56.236 years. The average CEO compensation (TC) is 6.450 million dollars. The average return on assets (ROA) is 5.845 return per asset. The average $R \& D$ intensity (RD) is $6.176 R \& D$ spending per sale. The average advertising intensity (AD) is 2.366.

In Table 3, sales (NSA) have the largest standard deviation 312.974 because NSA is skewed by some firms with extremely large sales compared with the rest of the sampled firms. CEO ownership (OWN) has the second largest standard deviation $\mathbf{5 9 . 2 7 0}$ due to the fact that OWN is skewed by some CEOs holding considerable amount of shares compared with the rest of the sample CEOs. Return on assets (ROA) has the third largest standard deviation 10.021 on the ground that ROA is skewed by some firms with extremely low negative performance compared with the rest of the sample firms. We can observe from Table 4 that the sample data do not have the multicollinearity problem.

\section{ESTIMATION RESULTS AND A COMPARISON OF THE OLS, 2SLS, AND 3SLS ESTIMATES}

The structural coefficients of the simultaneous CEO compensation model consisting of Eqs. (4.1) - (4.4) are estimated by OLS, $2 S L S$, and 3SLS. 3SLS becomes more efficient than 2 SLS if the cross-equation error terms $\varepsilon$ are correlated (Zellner \& Theil, 1962). Table 5 reports the estimation results by OLS, 2SLS, and 3 SLS. 
Table 5. Coefficient Estimates for the Structural-Form of the SES Model

\begin{tabular}{clllllllll}
\hline Hypothesis & \multicolumn{1}{c}{$\mathbf{1 A}$} & \multicolumn{1}{c}{$\mathbf{1 B}$} & $\mathbf{2 A}$ & $\mathbf{2 B}$ & $\mathbf{3}$ & $\mathbf{4 A}$ & $\mathbf{4}$ & $\mathbf{5}$ \\
\hline Coefficient & $\beta_{32}$ & $\beta_{32}$ & $\beta_{33}$ & $\beta_{33}$ & $\beta_{34}$ & $\beta_{24}$ & $\beta_{24}$ & $\beta_{42}$ \\
Sign & + & - & + & - & - & + & - & - \\
OLS & 0.087 & 0.087 & -0.002 & -0.002 & 0.224 & -0.001 & -0.001 & -0.021 \\
2SLS & -0.334 & -0.334 & 0.002 & 0.002 & -4.371 & 0.001 & 0.001 & -0.011 \\
3SLS & -0.179 & -0.179 & $0.010^{* *}$ & $0.010^{* *}$ & -0.068 & -0.015 & -0.015 & - \\
Hypothesis & $6 \mathrm{~A}$ & $6 \mathrm{~B}$ & 7 & 8 & 9 & 10 & 11 & \\
Coefficient & $\beta_{31}$ & $\beta_{31}$ & $\beta_{41}$ & $\beta_{22}$ & $\beta_{23}$ & $\beta_{21}$ & $\beta_{11}$ & \\
Sign & + & - & + & + & + & + & + & \\
OLS & $-0.201^{* * *}$ & $-0.201^{* * *}$ & -0.003 & $-0.285^{* * *}$ & -0.105 & $0.233^{* *}$ & $0.086^{* *}$ & \\
2SLS & $-2.889^{* *}$ & $-2.889^{* *}$ & 0.113 & -0.189 & 2.794 & 0.277 & $0.641^{* * *}$ & \\
3SLS & $-2.577^{* *}$ & $-2.577^{* *}$ & $0.145^{*}$ & $\underline{-0.225 t}$ & $2.348^{* *}$ & $0.613^{* * *}$ & $0.647^{* * *}$ &
\end{tabular}

† marginally significant at the 0.1 level; * significant at the 0.05 level; ** significant at the 0.01 level; and *** significant at the 0.001 level.

In the first place, we observe from Table 5 that four of the OLS signs that are underlined $\left(\beta_{34}, \beta_{41}\right.$, $\left.\beta_{22}, \beta_{23}\right)$ are contrary to the expected signs. All of the 2SLS and 3SLS signs match the expected directions except $\beta_{22}$ which will be discussed in Section 5. The four abnormal signs are caused by the simultaneity and endogeneity biases arising from the inappropriate application of OLS to estimate Eqs. (4.1) - (4.4). Thus, we conclude that 2 SLS and 3SLS are more appropriate than OLS for estimating the structural Eqs. (4.1) - (4.4) of the simultaneous CEO compensation model presented in Figure 1.

In the second place, we also can observe from Table 5 that 3 SLS is more efficient than $2 S L S$. There are seven significant 3SLS structural coefficients estimates (including marginally significant) compared to two significant 2SLS structural coefficients estimates. This suggests that some other contextual criteria variables are unintentionally omitted from the simultaneous CEO compensation model, because it is theoretically and practically impossible to include all contextual criteria variables.

In the third and final place, the 2SLS and 3SLS estimates of the reduced-form coefficients of Eqs. (4.5) - (4.8) can be obtained via the relationship between the structural coefficients and the reducedform coefficients (see Kmenta, 1997; Lin and Shao, 2000; Greene, 2012). Table 6 presents the estimates of each equation of the reduced form separately, obtained by $2 S L S$ and $3 S L S$; and Table 7 provides a summary of the 2 SLS and 3 SLS coefficient estimates of the reduced form. Then, Table 8 presents the total effect of one exogenous contextual criteria variable upon each and every endogenous variable considered in this study. 
Table 6. The 2SLS and 3SLS Estimated Results of Each Equation of the Reduced Form Eqs. (4.5) - (4.8) 2SLS Estimates 3SLS Estimates

$\begin{array}{ll}\widehat{T C}_{i}=2.046-1.004 T E N_{i}+0.007 N S A_{i} & \widehat{T C}_{i}=6.188-0.082 T E N_{i}+0.005 N S A_{i} \\ -13.156 V O L_{i}-0.018 O W N_{i} & -0.031 V O L_{i}+0.030 O W N_{i} \\ +0.485 A G E_{i}-0.151 \text { IND }_{i} & +0.031 A G E_{i}-0.240 I N D_{i} \\ \widehat{R O A}_{i}=-1.020-1.565 T E N_{i}+0.010 N S A_{i} & \widehat{R O A}_{i}=5.440-0.127 T E N_{i}+0.007 N S A_{i} \\ -20.509 \mathrm{VOL}_{i}-0.027 O W N_{i} & -048 V O L_{i}+0.047 O W N_{i} \\ +0.757 A G E_{i}-0.235 \text { IND }_{i} & +0.047 A G E_{i}-0.372 I N D_{i} \\ \widehat{R D}_{i}=33.302+4.188 T E N_{i}-0.028 N S A_{i} & \widehat{R D}_{i}=7.860+0.148 T E N_{i}-0.008 N S A_{i} \\ +54.873 V O L_{i}+0.079 O W N_{i} & +0.056-0.120 O W N_{i} \\ -2.186 A G E_{i}+0.680 \operatorname{IND}_{i} & -0.122 A G E_{i}+0.859 I N D_{i} \\ \widehat{A D}_{i}=2.182-0.178 T E N_{i}+0.001 N S A_{i} & \widehat{A D}_{i}=2.388-0.018 T E N_{i}+0.001 N S A_{i} \\ -2.326 V O L_{i}-0.003 O W N_{i} & -0.007 V O L_{i}+0.007 O W N_{i} \\ +0.075 A G E_{i}-0.023 \operatorname{IND}_{i} & +0.005 A G E_{i}-0.004 I N D_{i}\end{array}$

Note: A hat $\left({ }^{\wedge}\right)$ above a jointly dependent variable means the fitted value of the jointly dependent variable 
Table 7. A Summary of the 2SLS' and 3SLS' Coefficient Estimates of the Reduced Form of the SES Model Coefficient Estimate

\begin{tabular}{|c|c|c|}
\hline Reduced-Form Coefficient & by 2 SLS & by 3 SLS \\
\hline$\pi_{10}$ & 2.046 & 6.188 \\
\hline$\pi_{11}$ & -1.004 & -0.082 \\
\hline$\pi_{12}$ & 0.007 & 0.005 \\
\hline$\pi_{13}$ & -13.156 & -0.031 \\
\hline$\pi_{14}$ & -0.018 & 0.030 \\
\hline$\pi_{15}$ & 0.485 & 0.031 \\
\hline$\pi_{16}$ & -0.151 & -0.240 \\
\hline$\pi_{20}$ & -1.020 & 5.440 \\
\hline$\pi_{21}$ & -1.565 & -0.127 \\
\hline$\pi_{22}$ & 0.010 & 0.007 \\
\hline$\pi_{23}$ & -20.509 & -0.048 \\
\hline$\pi_{24}$ & -0.027 & 0.047 \\
\hline$\pi_{25}$ & 0.757 & 0.047 \\
\hline$\pi_{26}$ & -0.235 & -0.372 \\
\hline$\pi_{30}$ & 33.302 & 7.860 \\
\hline$\pi_{31}$ & 4.188 & 0.148 \\
\hline$\pi_{32}$ & -0.028 & -0.008 \\
\hline$\pi_{33}$ & 54.873 & 0.056 \\
\hline$\pi_{34}$ & 0.079 & -0.120 \\
\hline$\pi_{35}$ & -2.186 & -0.122 \\
\hline$\pi_{36}$ & 0.680 & 0.958 \\
\hline$\pi_{40}$ & 2.182 & 2.388 \\
\hline$\pi_{41}$ & -0.178 & -0.018 \\
\hline$\pi_{42}$ & 0.001 & 0.001 \\
\hline$\pi_{43}$ & -2.326 & -0.007 \\
\hline$\pi_{44}$ & -0.003 & 0.007 \\
\hline$\pi_{45}$ & 0.075 & 0.005 \\
\hline$\pi_{46}$ & -0.023 & -0.004 \\
\hline
\end{tabular}

Table 8. Total Effects

\begin{tabular}{ccccc}
\hline & \multicolumn{3}{c}{ Structural Form } & \multicolumn{2}{c}{ Reduced Form } \\
Jointly Determined Endogenous Variable & 2SLS & 3SLS & 2SLS & 3SLS \\
\hline CEO compensation (TC) & 0.641 & 0.647 & -13.837 & -0.287 \\
Firm performance (ROA) & 2.883 & 2.721 & -21.569 & -0.446 \\
R\&D intensity (RD) & -7.592 & -2.814 & 57.606 & 0.912 \\
Advertising intensity (AD) & 0.105 & 0.189 & -2.454 & -0.021 \\
\hline
\end{tabular}


Now, we observe from Table 7 that 3 SLS differs from 2 SLS in the signs of $\pi_{14}, \pi_{20}, \pi_{24}, \pi_{34}$, and $\pi_{44}$, that the signs of the estimates of other elements of $\Pi$ match between 2 SLS and $3 S L S$, and that all the signs of the 2SLS and 3SLS estimates of the elements of $\Pi$ are consistent with the expected directions, except for $\pi_{15}, \pi_{25}, \pi_{33}$, and $\pi_{45}$. From the theoretical and empirical points of view, it is difficult to decide whether 3 SLS is better than 2SLS for the reduced-form coefficients and the total effect estimation. However, since 3SLS indeed performs more efficiently than 2SLS for the structuralform coefficients estimation, we conclude that, overall, 3SLS is a better choice than 2SLS for the simultaneous CEO compensation model (cf. the empirical results of 3SLS in Lin, 1992; Lin and Shao, 2000).

\section{DISCUSSION}

\section{EFFECTS OF CONTEXTUAL CRITERIA}

First of all, we find that CEO's tenure as a contextual criterion has a negative effect on R\&D intensity. Because the sign does not match the theoretical prediction of Hypothesis $1 \mathrm{~A}$, Hypothesis $1 \mathrm{~A}$ is not supported. Although the negative sign matches the theoretical prediction of Hypothesis $1 \mathrm{~B}$, it is not significant. Thus, Hypothesis $1 \mathrm{~B}$ is also not supported. However, the $3 S \mathrm{SS}$ insignificant and negative estimate is consistent with the regression results of Barker and Mueller's (2002) Models 2 and 3 (p.794).

Secondly, firm size (sales) has a significant and positive impact upon R\&D intensity at the $1 \%$ level $\left(\beta_{33}=0.010\right.$ from 3SLS). Thus, Hypothesis $2 \mathrm{~A}$ is supported by the $3 \mathrm{SLS}$ estimate. However, Hypothesis $2 \mathrm{~B}$ is not supported empirically. Our positive and significant estimate is consistent with the resourcebased view theory (Schumpeter, 1942; Galbraith, 1952; Arrow, 1962), but it is contrary to Barker and Mueller's (2002) finding of a negative relationship between firm size and R\&D intensity in their main regressions (Models 1-3) (p.794). As such, our result suggests that larger firms are capable of investing more in R\&D because they have adequate resources and substantial power to initiate R\&D projects, successfully commercialize new products, and protect them from imitation.

Thirdly, market risk (beta) has a negative effect on R\&D intensity. The sign is as expected but it is not significant. Thus, Hypothesis 3 is not supported statistically. Our result is consistent with Lee's (2009) estimate based on fixed effects models filled into a panel data set.

Fourthly, CEO ownership has a negative impact on firm performance measured as ROA. The sign is at variance with the theoretical prediction of Hypothesis $4 \mathrm{~A}$. Thus, Hypothesis $4 \mathrm{~A}$ is not supported by our empirical estimate. Furthermore, although the sign matches the theoretical prediction of Hypothesis $4 \mathrm{~B}$, it is not significant. Thus, Hypothesis $4 \mathrm{~B}$ is also not supported. The sign confirms Welbourne and Cyr's (1996) finding of a negative relationship between CEO ownership and firm performance, but it is contrary to what Lilienfeld-Toal and Ruenzi (2014) have discovered.

Fifthly and finally, CEO's Age has a negative effect on advertising intensity (AD). The negative sign meets the theoretical expectation, but the estimate is statistically insignificant. Thus, Hypothesis 5 is not supported.

\section{SIMULTANEOUS RELATIONSHIPS: MANAGERIAL DISCRETION, FIRM PERFORMANCE, AND CEO PAY}

Both the 2 SLS estimate $\left(\beta_{31}=-2.889 * *\right)$ and 3SLS estimate $\left(\beta_{31}=-2.577 * *\right)$ at the $1 \%$ level of significance strongly suggest that firm performance (ROA) has a significant and negative effect on R\&D intensity, thereby confirming Hypothesis $6 \mathrm{~B}$ but rejecting Hypothesis $6 \mathrm{~A}$. This finding implies that turning around poor performance is a strong incentive for R\&D investment, which is consistent with conventional wisdom of Cyert and March (1963). 
Firm performance (ROA) has a significant and positive impact on advertising intensity (AD) at the $5 \%$ level $\left(\beta_{41}=0.145 *\right.$ from $\left.3 S L S\right)$. Hence, Hypothesis 7 is supported by the 3 SLS estimate. This finding suggests that advertising is the main route for high-performing firms to sustain market superiority and profitability. Note that this is an example where Hypothesis 7 would be rejected if the insignificant 2SLS estimate (0.113) were applied.

R\&D intensity has a marginally significant and negative effect on firm performance at the $10 \%$ level $\left(\beta_{22}=-0.225+\right.$ from 3 SLS). Thus, Hypothesis 8 is marginally not supported by the empirical estimate. This finding seems to contradict conventional thinking and intuition and is contrary to Lee's (2009) discovery. But, it becomes logical if we consider Hypothesis 6B and Hypothesis 8 jointly. When performance is low, firms will invest more in R\&D hoping to boost performance. However, as R\&D investment increases, our simultaneous equations model predicts decreasing performance. Logically, firms will reduce $R \& D$ expenditure. Therefore, R\&D spending appears to be an inverted U-shape relating to firm performance. This is consistent with the finding of Yeh, et al. (2010). The relationship between R\&D intensity and firm performance is not simple, causal and direct as suggested by both Lee (2009) and Beneda and Zhang (2011). Instead, it is quite complex as evidenced by the simultaneous CEO compensation model developed in this paper. This again affirms that top management team (TMT) has to consider managerial discretion (e.g., R\&D investment) and firm performance simultaneously and jointly. Note that this is a second instance where Hypothesis 8 would be rejected outright by the insignificant 2 SLS estimate $(-0.189)$ and decisively supported by the OLS estimate ($0.285^{* * *}$ ).

Advertising has a significant and positive impact on firm performance (ROA) at the $1 \%$ level $\left(\beta_{23}=\right.$ $2.348 * *$ from $3 \mathrm{SLS}$ ). Accordingly, $\mathrm{H} 9$ is firmly supported by the 3 SLS estimate. This is consistent with Shepherd's (1972) empirical result but contrary to Lee's (2009). Our finding confirms Shepherd's (1972) claim that advertising is a market barrier factor for profitability. It is noted that this is a third example where $\mathrm{H} 9$ would be rejected, provided that the insignificant 2SLS estimate (2.794) were utilized.

CEO compensation has a significant and positive effect on firm performance (ROA) at the $0.1 \%$ level $\left(\beta_{21}=0.613 * * *\right.$ from $\left.3 S L S\right)$. Thus, Hypothesis 10 is supported by the 3 SLS estimate. This evidence suggests that although solving the issue of pay inequality is important, restraining too much on CEO compensation might adversely affect firm performance, which consequently might lead to economic downturn. Once more, this is a fourth (final) example where $\mathrm{H} 10$ would be rejected, should the insignificant 2SLS estimate (0.277) be applied.

Firm performance (ROA) has a significant and positive impact on CEO compensation at the $0.1 \%$ level $\left(\beta_{11}=0.641 * * *\right.$ from 2 SLS and $\beta_{11}=0.647 * * *$ from $\left.3 \mathrm{SLS}\right)$. Therefore, Hypothesis 11 is supported. This is consistent with the agency theorists' assertion that performance is a strong incentive alignment mechanism tying CEO's interests with shareholder's interests and CEOs indeed are paid for performance (Kaplan, 2008). But, it is contrary to the findings of Finkelstein and Boyd (1998) and Tosi, et al. (2000). Our finding suggests that the relationship between firm performance and CEO compensation is not so simple and direct as suggested by previous studies and that this relationship must be considered simultaneously and jointly with managerial discretion under the impact of the contextual criteria as implied by the proposed simultaneous CEO compensation model estimated by a more rigid and appropriate 3SLS method, rather than a 2SLS or an OLS estimation. The SES model has shown to be a better alternative to explaining the cause-and-effect relationships between managerial discretion and firm performance, between firm performance and CEO compensation, and between managerial discretion and CEO compensation.

Figure 2 illustrates the simultaneous CEO compensation model with the hypotheses and the corresponding structural coefficient estimates from 3 SLS. 


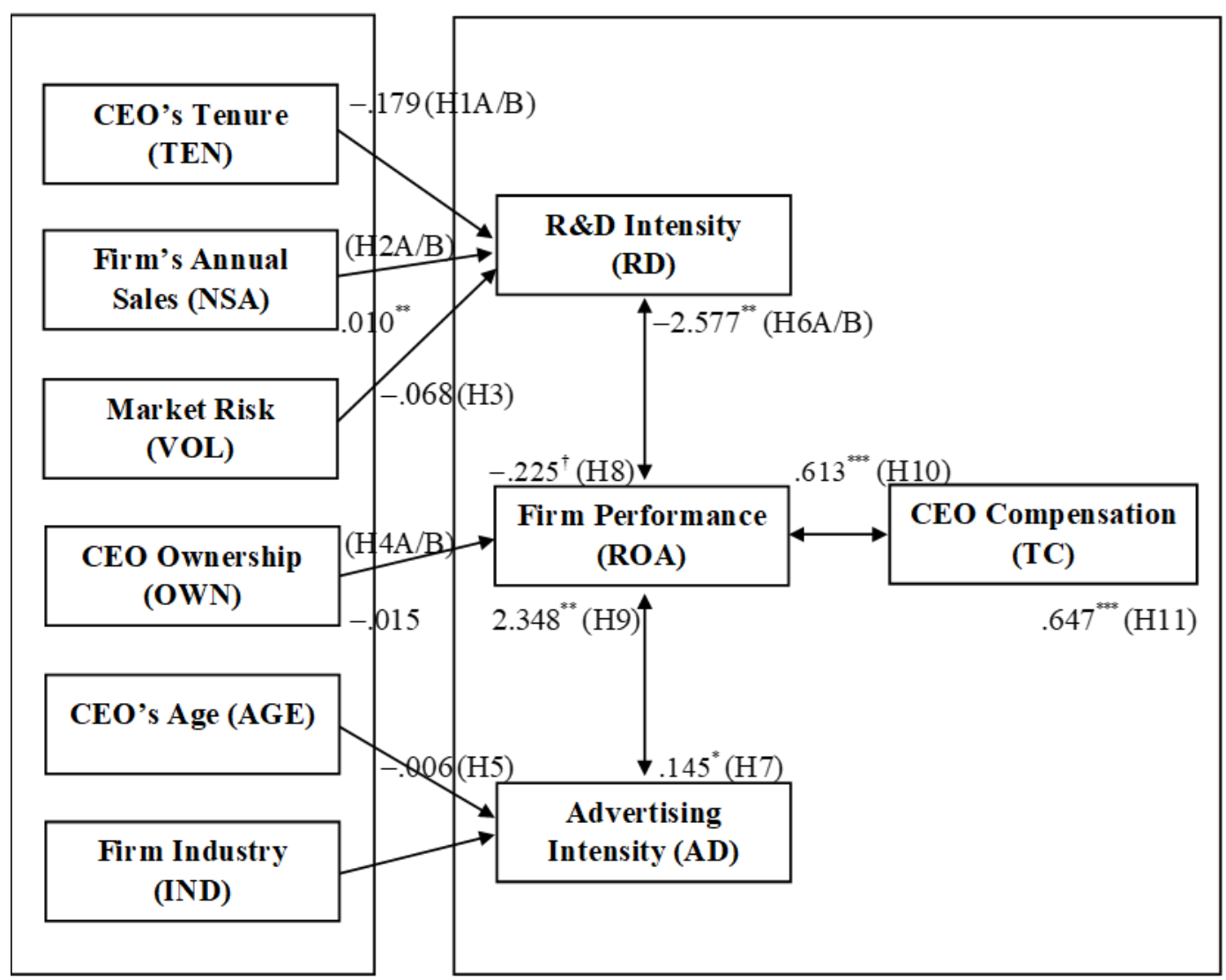

(† marginally significant at the 0.1 level; * significant at the .05 level; $* *$ significant at the .01 level; ***significant at the .001 level)

Figure 2. Hypotheses and 3SLS Coefficient Estimates of the Simultaneous Compensation Model

\section{TOTAL EFFECTS OF EXOGENOUS VARIABLES ON THE JOINTLY-DETERMINED ENDOGENOUS VARIABLES}

As mentioned earlier, Table 7 presents the total effects of exogenous variables on the jointlydetermined endogenous variables, which are computed based on the structural and reduced-form coefficient estimates from 2SLS and 3SLS.

The structural (or direct) total effect on a jointly-determined endogenous variable includes the effect of other endogenous variable(s) and the exogenous contextual criteria variable(s) present in a given equation. In comparison, the reduced (or indirect) total effect on a jointly-determined endogenous variable includes the combined effects of all the exogenous contextual criteria variables in the simultaneous CEO compensation model. The difference between 2 SLS and 3SLS is smaller in the structural form than in the reduced form, since the structural form indicates the direct summed effects of the variables in a given equation related to that endogenous variable whereas the reduced form shows the indirect compound effects of all the exogenous contextual criteria variables on each and every endogenous variable. 
For CEO compensation (TC), the structural total effect ( 0.641 from 2 SLS and 0.647 from $3 S L S$ ) is the same as the direct effect of firm performance (ROA), because firm performance (ROA) is the only jointly-determined endogenous variable in the CEO compensation equation (Eq. 3.1).

\section{MANAGERIAL IMPLICATIONS}

We can draw several managerial implications for board of director (BOD), top management team (TMT), chief executive officer (CEO), and policy maker. First and most importantly, this study confirms the positive contribution of firm performance to CEO compensation and the positive reverse impact of CEO compensation on firm performance. Hence, on the one hand, CEO compensation committee and other concerned parties should pay close attention to CEO's performance contingent on the managerial decisions and contextual criteria. On the other, overly restraining the CEO pay might adversely affect firm performance.

Such a need for attention to performance is especially critical when performance is jointly considered with managerial discretion and strategic choices, such as R\&D investment and advertising expenditure. Even though the feedback loop is positive between advertising spending and firm performance, it is negative between R\&D investment and firm performance. Therefore, CEOs should restrain from investing too much in R\&D and seek out the most optimal, efficient, and cost-effective R\&D spending threshold based on management studies (e.g., Yeh, et al., 2010) and job experience.

Managers should also focus on firm size that as a contextual criterion has a significant direct and indirect effect on R\&D and advertising decisions, firm performance, and CEO compensation which are jointly determined. Too big of a firm size might entice CEOs to invest too much in R\&D, which would lead to poor performance and consequently pay decrease. Hence, firm size does matter in firm performance but it should not be considered alone. Instead, it must be considered carefully and jointly with R\&D, advertising, and CEO compensation.

\section{CONCLUSIONS AND PROPOSING A MAJOR EXTENSION FOR FURTHER RESEARCH}

The agency theory predicts a positive effect of firm performance on CEO compensation, while the managerial entrenchment theory claims a negative effect and even no effect of firm performance on CEO compensation. Although many studies have been conducted, the debate on the relationship between firm performance and CEO compensation is still ongoing. We contribute to the literature by pointing out two important aspects overlooked by previous studies. First, the complex relationships among CEO pay, firm performance, and other relevant variables are not so simple, casual, and direct (or sequential) as suggested by previous studies. Instead, it is simultaneously and jointly determined along with managerial discretion such as R\&D and advertising intensity. Second, the jointlydetermined managerial discretion, firm performance, and CEO compensation should not be taken for granted and must be scrutinized under the direct and indirect impact of the contextual criteria. To bridge these two research gaps, a simultaneous CEO compensation model based on established management theories, psychology theories of motivation, and the results of previous studies is proposed and empirically tested to examine the proposition that the relationships among managerial discretion, firm performance, and CEO compensation are not sequential but rather simultaneously and jointly determined.

The three-stage least squares ( $3 S L S$ ) estimation results confirm a positive feedback loop between firm performance and CEO compensation, a positive feedback loop between firm performance and advertising intensity, and a negative feedback loop between firm performance and R\&D intensity. The empirical evidence implies that the positive relationship between firm performance and CEO compensation is contingent upon the appropriateness of the strategic choices that CEOs make and 
that excessive R\&D investment will hurt firm performance rather than help it. As such, it is important that managers find an optimal, efficient, and cost-effective R\&D spending threshold. Moreover, the 3SLS results indicate a significant and positive impact of firm size on R\&D intensity. But, managers should resist the temptation of abundant resources available from large size to spend too much on $R \& D$, which results in poor performance and low pay.

We conclude this study by suggesting that the cause-and-effect (interdependence or two-way) approach is in sharp contrast to the sequential (causality or one-way) approach and that the former is superior for understanding the simultaneous relationships among managerial discretion, firm performance, and CEO compensation in applied research of executive compensation and leadership. This study answers the call of new, rigorous and sophisticated methodology for CEO compensation research (Frydman \& Jenter, 2010; Devers et al., 2007) and CEO hiring research (Shi \& de Jong, 2020). We hope that more studies answering this call are forthcoming.

Finally, as a major and important extension to this study for future research, we propose to construct a dynamic simultaneous equations system (DSES) in line with the methodological and empirical studies by Theil and Boot (1962), Theil (1971), Zellner and Palm (1974), and Lin (1987, 1992). Based on the DSES, we will be able to analyze the initial, cumulated, and total effects of varying exogenous variables and lagged endogenous variables upon the four endogenous variables. 


\section{REFERENCES}

Adam, A. (2008). Handbook of Asset and Liability Management: From Models to Optimal Return Strategies. New York: John Wiley \& Sons.

Amato, L. J., \& Amato, C. H. (2004). Firm size, strategic advantage, and profit rates in US retailing. Journal of Retailing and Consumer Services, 11: 181-193.

Amato, L., \& Wilder, R. (1985). The effects of firm size on profit rates in US manufacturing. Southern Economic Journal, 52:181-190.

Arrow, K. (1962). Economic Welfare and the Allocation of Resources for Invention. The Rate of Inventive Activity. Princeton, NJ: Princeton University Press.

Bain, J. (1956). Barriers to New Competition. Cambridge, MA: Harvard University Press.

Barker III, V. L., \& Mueller, G. C. (2002). CEO characteristics and firm R\&D spending. Management Science, 48: 782-801.

Beneda, N., \& Zhang, Y. (2011). Research and development expenditures may not payoff in long run for IPO firms. Corporate Finance Review, 15: 28-32.

Boyd, B. K. (1990). Corporate linkages and organizational environment: A test of the resource dependence model. Strategic Management Journal, 11: 419-430.

Child, J. (1974). Managerial and organization factors associated with company performance. Journal of Management Studies, 11: 13-27.

Cyert, R. M., \& March, J. G. (1963). A Behavioral Theory of the Firm. Englewood Cliffs, NJ: Prentice-Hall.

Demsetz, H., \& Lehn, K. (1985). The structure of corporate ownership: Causes and consequences. Journal of Political Economy, 93: 1155-1177.

Devers, C. E., Cannella, Jr., A. A., Reilly, G. P. \& Yoder, M. E. (2007). Executive compensation: A multidisciplinary review of recent developments. Journal of Management, 33: 1016-1072.

Finkelstein, S., \& Boyd, B. K. (1998). How much does the CEO matter? The role of managerial discretion in the setting of CEO compensation. Academy of Management Journal, 41: 179-199.

Frydman, C., \& Jenter, D. (2010). CEO compensation. Annual Review of Financial Economics, 2: 75-102.

Gabaix, X., \& Landier, A. (2008). Why has CEO pay increased so much? The Quarterly Journal of Economics, 123: 49-100.

Galbraith, J. K. (1952). American Capitalism, The Concept of Countervailing Power. Boston: Mifflin Company.

Gillespie, G. (1991). Manufacturing Knowledge, A History of the Hawthorne Experiments. Cambridge: Cambridge University Press.

Goldberger, A. S. (1964). Econometric Theory. New York: Wiley.

Gomez-Mejia, L., \& Wiseman, R. M. (1997). Reframing executive compensation: An assessment and outlook. Journal of Management, 23(3): 291-374.

Greene, W. H. (2012). Econometric Analysis, $7^{\text {th }}$ Edition. Boston, MA: Pearson.

Hall, B. J., \& Liebman, J. B. (1998). Are CEOs really paid like bureaucrats? Quarterly Journal of Economics, 113: 653-691.

Hambrick, D. C., \& Fukutomi, G. D. (1991). The seasons of a CEO's tenure. Academy of Management Review, 16: 719-742.

Hambrick, D. C., \& Mason, P. A. (1984). Upper echelons: The organization as a reflection of its top managers. Academy of Management Review, 9: 193-206.

Hart, P., \& Mellons, J. (1970). Management youth and company growth: A correlation? Management Decision, 4: 50-53.

Hausman, J. (1978). Specification tests in econometrics. Econometrica, 46: 1251-1271.

Herzberg, F., Mausner, B., \& Snyderman, B. B. (1959). The Motivation to Work, $2^{\text {nd }}$ Ed., New York: John Wiley. 
Himmelberg, C., Hubbard, R., \& Palia, D. (1999). Understanding the determinants of managerial ownership and the link between ownership and performance. Journal of Financial Economics, 53: 353-384.

Hirshleifer, D., Low, A., \& Teoh, S. H. (2012). Are overconfident CEOs better innovators? Journal of Finance, 67: 1457-1498.

Hogan, T. D., \& McPheters, L. R. (1980). Executive compensation: Performance versus personal characteristics. Southern Economic Journal, 46: 1060-1068.

Jensen, M. C., \& Meckling, W. H. (1976). Theory of the firm: Managerial behavior, agency costs and ownership structure. Journal of Financial Economics, 3: 305-360.

Jensen, M. C., \& Murphy, K. J. (1990). Performance pay and top-management incentives. Journal of Political Economy, 98: 225-264.

Kaplan, S. (2008). Are U.S. CEOs overpaid? Academy of Management Perspectives, 22: 5- 20.

Kim, E. H., \& Lu, Y. (2011). CEO ownership, external governance, and risk-taking. Journal of Financial Economics, 102: 272-292.

Kmenta. J. (1997). Elements of Econometrics, $2^{\text {nd }}$ Ed., Ann Arbor, MI: The University of Michigan Press. Koutsoyiannis, A. (1977). Theory of Econometrics, $2^{\text {nd }}$ Ed., New York: Macmillan.

Lee, J. (2009). Does size matter in firm performance? Evidence from US public firms. International Journal of the Economics of Business, 16: 189-203.

Lilienfeld-Toal, U. V., \& Ruenzi, S. (2014). CEO ownership, stock market performance, and managerial discretion. Journal of Finance, 69: 1013-1050.

Lin, W. T. (1987). Dynamic behavior of public investments: A dynamic simultaneous-equation system approach. International Journal of Systems Science, 18: 2145-2173.

Lin, W. T. (1992). Analysis and forecasting of income statement account balances: The dynamic interdependency and ARIMA approaches. Journal of Forecasting, 11: 283-307.

Lin, W. T., \& Shao, B. B. M. (2000). The relationship between user participation and system success: A simultaneous contingency approach. Information \& Management, 37: 283-295.

Lin, W. T., \& Chiang, C. Y. (2011). The impacts of country characteristics upon the value of information technology as measured by productive efficiency. International Journal of Production Economics, 132: 13-33.

Lin, W. T., \& Shi, J. (2020). Chief executive officer compensation, firm performance, and strategic coopetition: A seemingly unrelated regression approach. Managerial and Decision Economics, 41: 130-144.

Maslow, A. H. (1943). A theory of human motivation. Psychological Review, 50: 370-396.

Maslow, A. H. (1954). Motivation and Personality. New York: Harper and Row.

Mayo, E. (1946). The Human Problems of an Industrial Civilisation, $2^{\text {nd }}$ Ed., Cambridge, MA: Harvard University.

Mayo, E. (1975). The Social Problems of an Industrial Civilisation (later ed. with appendix). London: Routledge and Kegan Paul.

McConnell, J., \& Servaes, H. (1990). Additional evidence on equity ownership and corporate value. Journal of Financial Economics, 27: 595-612.

Miller, D. (1991). Stale in the saddle: CEO tenure and the match between organization and environment. Management Science, 37: 34-52.

Miller, D., Vries, M. F. R., Kets de, \& Toulouse, J. M. (1982). Top executive locus of control and its relationship to strategy-making, structure, and environment. Academy of Management Journal, 25: 237-253.

Morck, R., Shleifer, A., \& Vishny, R. (1988). Management ownership and market valuation. Journal of Financial Economics, 20: 293-315. 
Mueller, D. C. (1990). The persistence of profits in the United States. In D. C. Mueller (Ed.), The Dynamics of Company Profits: An International Comparison, Chapter 4, pp. 35-58. Cambridge: Cambridge University Press.

Nightingale, D., \& Toulouse, J.-M. (1977). Toward a multilevel congruence theory of organization. Administrative Science Quarterly, 22: 264-280.

Oliver, R. (1974). Expectancy is the probability that the individual assigns to work effort being followed by a given level of achieved task performance. Expectancy theory predictions of salesmen's performance. Journal of Market Research, 11: 243-253.

Perlitz, M., Peske, T., \& Schrank, R. (2002). Real options valuation: The new frontier in R\&D project evaluation. R\&D Management, 29: 255-270.

Quigley, T., \& Hambrick, D. C. (2015). Has the "CEO effect" increased in recent decades? A new explanation for the great rise in America's attention to corporate leaders. Strategic Management Journal, 36: 821-830.

Roethlisberger, F. J., \& Dickson, W. J. (1939). Management and the Worker: An Account of a Research Program Conducted by the Western Electric Company, Hawthorne Works, Chicago. Cambridge, MA: Harvard University Press.

Scherer, F. M., \& Ross, D. (1990). Industrial market structure and economic performance. Boston: Houghton Mifflin.

Schmalensee, R. (1977). Using the H-index of concentration with published data. Review of Economics and Statistics, 59: 186-193.

Schumpeter, J. (1942). Capitalism, Socialism, and Democracy. New York: Harper and Row.

Shepherd, W. G. (1972). The elements of market structure. Review of Economics \& Statistics, 54: 25-37.

Shi, J., \& de Jong, J. (2020). Insider or outsider? The separate and joint effects of firm performance and diversification on CEO recruitment. Journal of Management and Governance, 24: 91-115.

Shleifer, A., \& Vishny, R. W. (1989). Management entrenchment: The case of manager-specific investments. Journal of Financial Economics, 25: 123-139.

Smirnova, A. S., \& Zavertiaeva, M. A. (2017). Which came first, CEO compensation or firm performance? The causality dilemma in European companies. Research in International Business and Finance, 42: 658-673.

Stulz, R. (1988). Managerial control of voting rights: Financing policies and the market for corporate control. Journal of Financial Economics, 20: 25-54.

Theil, H., \& Boot, J. C. G. (1962). Review of the International Statistical Institute, 30: 136-152; reprinted in Zellner, A. (Ed.), Readings in Economic Statistics and Econometrics, Boston, MA: Little \& Brown, 1968, 611-630.

Theil, H. (1971). Principles of Econometrics, New York: Wiley.

Tosi, Jr., H. L., \& Gomez-Mejia, L. (1989). The decoupling of pay and performance: An agency theory perspective. Administrative Science Quarterly, 34: 169-180.

Tosi, H. L., \& Gomez-Mejia, L. R. (1994). CEO monitoring: A behavioral approach. Academy of Management Journal, 37: 1002-1016.

Tosi, H. L., Werner, S., Katz, J. P., \& Gomez-Mejia, L. R. (2000). How much does performance matter? A meta-analysis of CEO pay studies. Journal of Management, 26: 301-339.

Vroom, V. H. (1964). Work and Motivation. New York: Wiley.

Welbourne, T. M., \& Cyr, L. A. (1996). Using ownership as an incentive: Does the "too many chiefs" rule apply in entrepreneurial firms? (CAHRS Working paper \#96-14). Ithaca, NY: Cornell University, School of Industrial and Labor Relations, Center for Advanced Human Resources Studies. Access: http://digitalcommons.ilr.cornell.edu/cahrswp/184.

Wu, D. (1973). Alternative tests of independence between stochastic regressors and disturbances. Econometrica, 41: 733-750. 
Yeh, M.-L., Chu, H.-P., Sher, P. J., \& Chiu, Y.-C. (2010). R\&D intensity, firm performance and the identification of the threshold: Fresh evidence from the panel threshold regression model. Applied Economics, 42(3): 389-401.

Zellner, A., \& Theil, H. (1962). Three-stage least squares: Simultaneous estimation of simultaneous equations. Econometrica, 30(1): 54-78.

Zellner, A., \& Palm, F. (1974). Time series and simultaneous equation econometric models. Journal of Econometrics, 2: 17-54. 